\title{
LEARNING WITH OUR HANDS AND FROM OUR STUDENTS
}

\section{J. Cynthia McDermott}

Prof. Dr., Antioch University, The United States, cmcdermott@antioch.edu

\begin{abstract}
One lesson from the COVID-19 pandemic is our recognition of our dependence on others. Few of us can repair a broken light, change a tire, repair a broken window or repair the wide and myriad number of events that can occur. Instead we rely on workers; individual who use their hands (and their common sense and skills) to help us with daily tasks. This is a society that has forgotten how important these skills are. But it has not always been that way.

Thanks to the philosophy of John Dewey and the actions of William Wirt (who was his student and became the superintendent of the Gary Plan), by 1907 there was a clear understanding that individuals needed to have experience using their hands in what became known as industrial arts courses. In the Gary Plan students were encouraged to think about the vocations available. These manual training classes were taught by practitioners some of whom attended Teachers College which was founded in 1887 as an industrial education schools (Foster, 1995, p.12)

In the Gary Plan and schools modeled on it, students of all ages were given the opportunity to use their hands to produce a thing. When asked about work, the great cabinet maker Krenov (1996) described using his hands this way

Not long ago, I was asked "what does the word work mean to you. I guess it means doing what one thinks is worth doing and doing it well. As long as we have a feeling that comes from our core and lends a bit of warmth to what we do and touches people that our doing brings us in contact with then those of us who are times can be called wood-butchers are doing rather well, really (p. 50)
\end{abstract}

As a fine cabinetmaker he could have named any vocation; plumber, electrician, mechanic. During the COVID-19 lock down, who did you miss? Perhaps it was the butcher to cut your meat, the electrician to fix your lights or the mechanic when the engine light.

How were individuals prepared to work with their hands in the past? For folks who lived on the farm and in small communities where the technology of work was the use of hands, people learned by doing and by apprenticing with others. By the late 1800s a course of study known as "industrial arts" was becoming common in schools across the country.

Industrial arts was designed to develop an understanding of technology and its impact on their lives. And although not everyone is a producer of material culture, all are consumers and users of the products of industry. One of its main goals is the development of technology literacy for all students in order for them to understand ...technology (Schmitt, 1966, p 1-4). Schmitt describes the benefits of industrial arts education.

Industrial arts is an activity approach to learning, an opportunity for individualize student progression, an opportunity for helping students make career choices, an understanding of consumer products, a study of fundamental tools, materials and industrial processes and an understanding of industry and technology. These understandings lead to the development of a smarter consumer and individual with skills to support their own problems and concerns. Excellent benefits but today these opportunities are almost gone from our 
schools.

In a 1986 Los Angeles Times article, Moreland and Campbell write that shop classes, the wood, drafting, print, metal and other industrial arts courses that served as a rite of passage for several generations of menare fast disappearing from the high school curricula. Buffeted by budget cuts, outdated by modern technology and put on low priority because of stricter academic graduation requirements, shop classes are becoming a luxury elective that few students can afford to take.

What happened to create this change? The reason was and continues to be the increase in academic classes students need take to graduate and that "eliminated a student's' chances for exploration of different fields and making good career decisions.

Somewhere along the way as modern societies evolved, we lost the value we place on people who could "do" things and replaced it with people who could "think" things. We've lost sight that the people who do things also have to think things. So, we told our children to use their brains and not their brawn and become MBAs. Today MBAs are a dime a dozen, struggling to find employment, while a good carpenter is a rare find (Newell, 2014).

In fact, over the last 30 years, it is not uncommon to hear the message to young people that they must go to college. This issue is partly due to our culture's emphasis on going to college. Many high schools look to their university placement as the best judge of a quality education. That statistic discriminates against students for whom college is just not a good fit, especially when schools do little to inform students of noncollegiate options. It is unfortunate for those students who try college, but eventually drop out, feeling like a failure, when in fact, it wasn't the right place for them from the start (Chamberlain, 2019).

Chamberlain (2019) states that America is facing an unprecedented skilled labor shortage. According to the Department of Labor, prior to the virus 7.6 million unfilled jobs existed but only 6.5 million were looking for work. Since the end of WWII little attention has been paid to the infrastructure of roads, highways, bridges, locks, dams, harbors, water systems, airports and many public buildings.

Aside from federal infrastructure spending, projected job growth in many building trades continues to be positive. Through 2026 there is a projection of better than average employment in all of the building trades but the only problem is, there simply may not be enough workers to employ. Becoming aware of this situation can help to mitigate the challenges the world is facing.

Keywords: Mechanical technology, alternatives to college, skilled labor

\section{LEARNING WITH OUR HANDS AND FROM OUR STUDENTS}

Perhaps one of the most interesting lessons from the COVID-19 virus pandemic is our recognition of our dependence on others. Few of us can repair our own toilets, broken lights, change a tire, repair a broken window or repair the wide and myriad number of events that can occur. Instead we rely on an industry of "workers; individual who use their hands (and their common sense and skills) to help us with daily tasks. Even cutting hair, coloring our roots and trimming our toenails is left to others in a society that has forgotten how important these skills are. But it has not always been that way.

Thanks to the philosophy of John Dewey and the actions of William Wirt (who was his student and became the superintendent of the Gary Plan), by 1907 there was a clear understanding that individuals needed to have experience with a wide variety of what became known as industrial arts courses. In the Gary Plan which for a time was extremely popular across the world, students were encouraged to think about the vocations available. These manual training classes were taught by practitioners some of whom attended Teachers College which was founded in 1887 as an industrial education schools (Foster, 1995, p.12)

In the Gary Plan and schools modeled on it, students of all ages were given the opportunity to use their hands to produce a thing. When asked about work, the great cabinet maker Krenov (1996) described using his hands this way

Not long ago, I was asked "what does the word work mean to you. I guess it means doing what one thinks is worth doing and doing it well. As long as we have a feeling that comes from our core and lends a bit of warmth to what we do and touches people that our doing brings us in contact with then those of us who are times can be called wood-butchers are doing rather well, really (p. 50) 
As a fine cabinetmaker he could have named any vocation; plumber, electrician, mechanic, or any skill area that brings together skill and need in order to satisfy someone's wants. During the COVID-19 lock down, who did you miss? Perhaps it was the butcher to cut your meat, the electrician to fix your lights or the mechanic when the engine light came on and on and on. Working with your hands is a tradition as old as the human species.

How were individuals prepared to work with their hands in the past? For folks who lived on the farm and in small communities where the technology of work was the use of hands, people learned by doing and by apprenticing with others. By the late 1800s a course of study known as "industrial arts" was becoming common in schools across the country.

Industrial arts was designed to develop in young people an understanding of technology and its impact on their lives. And although not everyone is a producer of material culture, all are consumers and users of the products of industry. One of its main goals is the development of technology literacy for all students in order for them to understand ...technology (Schmitt, 1966, p 1-4). Schmitt describes the benefits of industrial arts education.

Industrial arts is an activity approach to learning, an opportunity for individualize student progression, an opportunity for helping students make career choices, an understanding of consumer products, a study of fundamental tools, materials and industrial processes and an understanding of industry and technology. These understandings lead to the development of a smarter consumer and individual with skills to support their own problems and concerns. Excellent benefits but today these opportunities are almost gone from our schools.

In a 1986 Los Angeles Times article, Moreland and Campbell (1986) write that shop classes, the wood, drafting, print, metal and other industrial arts courses that served as a rite of passage for several generations of men-are fast disappearing from the high school curricula. Buffeted by budget cuts, outdated by modern technology and put on low priority because of stricter academic graduation requirements, shop classes are becoming a luxury elective that few students can afford to take. It is also difficult to find instructors to teach those classes.

What happened to create this change? The reason was and continues to be the increase in academic classes students need take to graduate and that "eliminated a student's' chances for exploration of different fields and making good career decisions.

So what is the problem? Somewhere along the way as modern societies evolved, we lost the value we place on people who could "do" things and replaced it with people who could "think" things. We've lost sight that the people who do things also have to think things. So, we told our children to use their brains and not their brawn and become MBAs. Today MBAs are a dime a dozen, struggling to find employment, while a good carpenter is a rare find (Newell, 2014).

In fact, over the last 30 years, it is not uncommon to hear the message to young people that they must go to college. This issue is partly due to our culture's emphasis on going to college. Many high schools look to their university placement as the best judge of a quality education. That statistic discriminates against students for whom college is just not a good fit, especially when schools do little to inform students of noncollegiate options. It is unfortunate for those students who try college, but eventually drop out, feeling like a failure, when in fact, it wasn't the right place for them from the start (Chamberlain, 2019).

There is a larger problem than just finding an affordable and well-trained carpenter. Chamberlain (2019) states that America is facing an unprecedented skilled labor shortage. According to the Department of Labor, prior to the virus 7.6 million unfilled jobs existed but only 6.5 million were looking for work. Since the end of WWII little attention has been paid to the infrastructure of roads, highways, bridges, locks, dams, harbors, water systems, airports and many public buildings. There have been years of neglect or only marginal repair and each year the cost to fix or replace the crumbling systems soars, with estimates now in the multi trillions of dollars. And that's just to fix what's already there and falling apart.

Aside from federal infrastructure spending, projected job growth in many building trades continues to be positive. Through 2026 there is a projection of better than average employment in all of the building trades, but the only problem is, there simply may not be enough workers to employ.

There are additional solutions along without adding back industrial arts classes. Between 1933 and 1942 President Roosevelt faced a number of significant economic challenges as a result of the Great Depression with unemployment at almost $25 \%$. Some are saying that here is 2020 we are facing a similar situation with more than 23.1 million unemployed (Bureau of Labor Statistics, May 8, 2020) with a rate at $14.7 \%$ and 
seemingly increasing.

What did Roosevelt do as this situation created such horrors? He began the New Deal and developed the Civilian Conservation Corps (CCC) and the Works Project Administration. What is relevant to this issue of learning to use ones hands is the legacy of the CCC. Over a short period of time more than 7.7 million young people who were unemployed were given a new lease on life. The CCC trained young people to build, repair, create, invent and work together to create change in the community (O'Mara, 2020). The list of their accomplishments is not only outstanding but serves for support the notion that working with ones hands creates lasting infrastructure. But perhaps more importantly the CCC is credited with creating a sense of hard work and pride in the United States that fueled the behavior of the Greatest Generation. At its center stood there three achievements: improved physical condition, heightened morale and increased employability. We would use a bit of that now given our obesity, our low morale and the number of people who have no skills to be employed in the industries who so need employees.

Recognizing high tuition costs, long term student loan debt, and difficulties finding a job in the field of their college major should be motivating young men and women to look at better paying alternatives from the onset. Many are already skilled at working with their hands and prefer jobs where they can move around rather than sitting at a desk all day. High school career counselors would be doing students a big favor by informing them about the benefits of getting into technical trades. Parents who best understand their son or daughter's interests may also do well to encourage career options aside from immediately attending college. It's time we reduce the stigma around technical training. Skilled labor is not a fallback position, but a genuine positive career choice.

Many other areas of building trades continue to see considerable growth. Joelle Salerno, the Government Affairs director for National Electrical Contractors Association of Western PA said the nationwide market demand for skilled electricians will remain high. Currently, there are 16,000 job openings for electricians with more anticipated as many current electricians are near retirement age. Future jobs growth in the electrical field will be with energy efficiency, power over ethernet, and retrofitting buildings.

"We've drilled into children's heads 'college, college, college' all their life, and we need to get to students earlier to let them know of these career options," said Salerno. She noted that at some International Brotherhood of Electrical Workers training centers a student will earn an associate degree, all the while receiving a paycheck.

With tens of thousands of current job openings and hundreds of thousands anticipated over the coming year, my question is this: why aren't we telling more of our kids about these options for their future? A smart, dedicated, young man or woman develops a lot of life skills on the job. Technical careers demand the same level of leadership, collaborative teamwork, productivity, and problem solving in an equally complex and challenging environment as any other employment opportunity (Chamberlain, 2019).

Here is a personal story about the influence of industrial arts. When I started teaching high school students in a major inner city, I discovered most of them did not read (alliterates) and some of them could not read (illiterates). I had recently earned a Master's degree in reading and I believe that knew how to teach adolescents how to read or so I thought.

And then I met Floyd Smith. He was twenty, still a freshman, six feet three, two hundred pounds, an active gang member and illiterate. He attended two classes; auto shop and reading. His first day in my class went like this. Floyd came in and confronted me, moving me back and back and back against the wall. Finally, when I could retreat no further looking into the eyes of a student more than a foot taller than me, he said, "You are going to teach me to read Right Now!!!" How could I say anything but yes.

Cut forward a few weeks and things were not going well. I needed to find another way to connect Floyd to reading. Floyd had inherited an old Ford from his uncle who had been killed in a gang fight. Trouble was that the car had some kind of electrical problem which stopped the car in sometimes the most inopportune places. Floyd needed to repair this car in order to stay alive

I lived in the neighborhood and was visited by one of Floyd's friends. He made it clear that Floyd was in a very difficult position. Well I certainly knew nothing about cars so I went to see the Auto shop teacher to ask his ideas about what to do. A smart and clever man he told me about a book called the Chilton Manual and one is written for every car and contains every piece of information that you would need to know about the workings of a car. Floyd and I went to the local Pep Boys store in Germantown and bought the Chilton Manual and that became our reading text. Within a few weeks, Floyd was reading fluently from the Manual 
and it was only weeks before he made the transition from automotive language to other kinds of material.

To this day I credit Floyd as the most influential teacher I have ever had. I learned from him that the classroom needs to provide learners with experience that relates to what they already know, that creates opportunity for them to be successful from the very first moment, that the educational process needs to be meaningful and that the process needs to connect beyond the four walls of the classroom. As a National Trainer for Foxfire which supports this kind of John Dewey based philosophy, these are the principles that I encourage my students and faculty members to employ. And, of course, I try to put these ideals into practice in my daily work.

Something more important is also at work here. Floyd continued to attend the auto shop classes and repaired his car. He discovered that he was a natural mechanic and after graduation came back to the shop to volunteer with his shop teacher to help others become successful.

Floyd then had an opportunity. He was a poor kid, living in a poor neighborhood so employment was a challenge. But he began working for a mechanic a few neighborhoods distant part time. That changed into full time because he was so successful that the business for the shop grew. At some point the owner decided to retire and turned the shop over to Floyd. When I stopped by a few years later I got to meet his wife who ran the books, his son who was becoming a helper and his brother who was learning to be a mechanic.

Without shop class, the Chilton manual and the good graces of his shop teacher, I believe that Floyd would have landed on the street, for what else could he have done? Yes, he had learned to read but so late in his school career that he missed so much. Could he have gotten into a college? Maybe. Would he have been successful? Maybe. Would he have been able to provide for his entire family in such a successful way? Maybe. But the end of this tale is that shop class gave him a life and a profession. It is a clarion call that learning to use your hands can be just as productive as any other choice (and maybe more).

Today the mantel of industrial arts classes are being taken up by schools that are defined as "trade" schools often for profit or connected to community colleges (Grayson, 2019). They offer a broad array of courses but sadly they charge some form of tuition and there are pre-application requirements. Had the shop classes remained, which were part of the public school system, young people could learn these necessary and key employable fields for free. Perhaps one day we will return to such an option particularly as the job market continues to cry for well trained workers who know that working with their hands is just as valid as working with their heads.

\section{REFERENCE LIST}

Bureau of Labor Statistics. (2020, April). The employment situation. Retrieved from https://www.bls.gov/news.release/pdf/empsit.pdf

Chamberlain, S. (2019, August 21). Addressing the skilled labor shortage in American. Retrieved from https://www.forbes.com/sites/sarahchamberlain/2019/08/21/addressing-the-skilled-labor-shortage-inamerica/\#9e4576a181df

Foster, P. (1995). The founders of industrial arts in the U.S. Journal of Technical Education, 7(1).

Grayson, C. (2019, May 15). How trade schools can fill the growing need for young US manufacturing workers. Retrieved from

https://www.chooseamericanmetal.com/blog/how-trade-schools-can-fill-the-growing-need-for-young-u-smanufacturing-workers/

Krenov, J. (1993). The impractical cabinetmaker. Fresno, CA: Linden Publications.

Moreland, P. \& R. Campbell. (1986, June 12). High school shop classes soon may be a thing of the past. Retrieved from https://www.latimes.com/archives/la-xpm-1986-06-12-ga-10532-story.html

Newel, M. (2014, June 2). The death of industrial arts. Retrieved from

https://www.wanderer.com/features/the-death-of-industrial-arts/ 
Proceedings of SOCIOINT 2020- 7th International Conference on Education and Education of Social Sciences, 15-17 June 2020

O'Mara, C. (2020, May 18). 7.7 million young people are unemployed. Retrieved from https://www.nytimes.com/2020/05/18/opinion/coronavirus-unemployment-youth.html

Schmitt, M. (1966). Industrial arts education. Washington, D.C.: U.S. Department of Health, Education and Welfare. 